\title{
Intersections of African-American Womanist Literary Approaches and Paradigms of Ethical Literary Criticism
}

\author{
AGNIESZKA ŁOBODZIEC
}

\begin{abstract}
Although black American womanist literary perspectives and ethical literary criticism theory emerged from different socio-cultural contexts, a number of intersections between the two can be discerned. One of the objectives of this paper is to analyze the reasons for which some Chinese scholars and African-American women literary theoreticians are skeptical of mainstream Western literary criticism schools, which they view as insufficient for exploring works of literature derived from fusions of non-Western and Western cultural contexts. Secondly, the paper elucidates the particular value systems exhibited by fictional characters portrayed by the African-American women writers under survey. At this juncture, the means by which the writers challenge value systems based upon Western essentialist racial conceptualizations will be given primary attention. Also, the historical context of the development of womanist ethics and literary practice, particularly the manifestation of original social ethics in response to historical oppression, will be focused upon. Lastly, the didactic function of womanist literature will be considered because, more often than not, black American woman writers have endeavored to produce fiction that serves as guideposts towards conflict resolutions, involving, to a great extent, revaluation of mainstream values.
\end{abstract}

Keywords: ethical literary criticism; womanist ethics; womanist literature; values; ethical identity

\section{Enhancement of Mainstream Western Literary Criticisms}

Western literary theoreticians, particularly since the rise of Formalism and New Criticism, have contributed significantly to the systematization of various literary approaches at the academic level. The most influential schools, apart from Formalism and New Criticism, are Psychoanalysis, Feminism, Marxism, Post-colonialism, Structuralism, Deconstruction, New Historicism, and Reader-Response Criticism. Many attempts have been made to draw a line of demarcation between schools of literary criticism by ferreting out particular focal points such as form, structure, content, and roles of the author, reader, 
ŁOBODZIEC

and the literary work respectively. However, one of the most acknowledged though quite generalized differentiation regarding literary critical perspectives is between the so-called aesthetic and cultural approaches. In an introduction to Literary and Cultural Theory: From Basic Principles to Advanced Application, Donald E. Hall recapitulates this distinction:

[...] the millennia-long history of literary and cultural analysis is one of dramatic metamorphosis and expansion, from aesthetics-the study of beauty and the delineation of precise standards for judging art and expression-to an emphasis today on the study of culture and how aesthetic notions are produced in a given time and place. (Hall 2001: 1)

Nevertheless, the representatives of some literary circles find mainstream Western approaches insufficient or reductive. For instance, with regard to Feminism, Ecocriticism, New-historicism, and Post-colonialism, Nie Zhenzhao contends, "Although these critical theories put literature into dialogue with politics, morality, gender and ethnicities, there is a deficit of ethical engagement in them" (Nie 2015: 84). His statement appears very convincing in that most of the foregoing literary perspectives do not note the ethical dimensions of the subject matter they focus upon. Generally, when they examine such issues as social injustice rendered by racial, gender, and class discrimination, the devastation or commodification of nature by man, and western colonialist usurpation, they tend to view them as intricate cultural and psychological processes rather than immoral social orders and value systems. Within the mainstream Western literary circles, a systematized methodology offering an ethically oriented analysis of literary representations of social, political, and cultural phenomena has not been given full academic credence.

Correspondingly, several African American female literary theoreticians and writers regard mainstream Western critical approaches as inapplicable in analyzing black American women's literature, especially taking into consideration the fact that a primary objective of black American women's literary practice is to produce works of "a rich resource and a coherent commentary that brings into sharp focus the Black community's central values, which in turn frees Black folks from the often deadly grasp of parochial stereotypes" (Cannon 2003: 62). Some black female literary critics, among them Joyce Ann Joyce, believe that black critics and writers should "look within, to self and community, for the inspiration needed to shape a characteristically Black art” (Joyce 1994: 3).

There are several focal points and features of mainstream Western literary theories that a number of black American women scholars perceive to be deficient and irrelevant in exploration of the literary representations of the black 
community's experience and value system. From the 1980s, when womanist thought began to be systematized, certain African American women scholars have criticized the aridity of what they deemed to be jargonized academic expressiveness within Western literary theoretical circles that even some black American post-structuralist critics emulate. In 1988, referring to the off-putting nature of literary theoretical terminology, Barbara Christian noted, "as a student of literature, I am appalled by the sheer ugliness of the language, its lack of clarity, its unnecessarily complicated sentence constructions, its lack of pleasurableness, its alienating quality" (Christian 1988: 72). In the decade that followed, Joyce Ann Joyce likewise wrote,

Following the same methodological strategies characteristic of the works of Northrop Frye and poststructuralist critics like Roland Barthes, Paul de Man, Jacques Derrida, and Geoffrey Hartman, Black poststructuralist critics have adopted a linguistic system and an accompanying world view that communicate to a small, isolated audience. Their pseudoscientific language is distant and sterile. (Joyce 1996)

In response, Aoi Mori asserted, "[t] he responsibility of womanists is to discover a tangible language which can unite academic discourse and daily experience, preventing any dominating plethora of logocentrism” (Mori 1999:13).

The aforementioned black women critics do not oppose literary theory as such but reject its linguistic sophistry that limits its accessibility and comprehensibility to only an exclusive group of scholars instead of a wider audience. Such an approach stems from the endeavors of most African-American women literary scholars and writers to focus on literature's functionality, which corresponds with ethical literary criticism advocates, among them Nie Zhenzhao, who maintains, "By the teaching function of literature, ethical literary criticism can be used to help readers and learners to get enlightenment, education, instruction, and guidance as they analyze, interpret, comment on, and evaluate literary texts" (Ross 2015: 14). The ethical literary critical perspective is, to a large extent, a response to observed ambivalence in adopting Western literary thought within the Chinese context, where,

[o]n the one hand, this importing of Western critical theories contributed to the overall progression and flourishing of literary studies in China; on the other, large-scale translating and applying of Western literary theories brought complications. For example, scholars either tended to move away from literary texts in the name of theory or became too engrossed in theoretical, thematic and terminological complexity. (Baker and Shang 2015: 14) 
ŁOBODZIEC

Literary works and critical commentaries are more likely to function as ethical guidelines, appealing to the broadest audience possible, if they are not written in logocentric, sophisticated, jargonistic language. To sum up, both ethical literary criticism proponents and womanist literary advocates are of the opinion that rendering literary discourse more accessible to the audience beyond academic circles would enhance the mainstream Western literary schools.

\section{Ethical Collective Experience as a Fount of Womanist Literature}

Nie Zhenzhao outlines three elements of the cultural context from which literature arose which include "the need of humans to express their views on ethic $[s]$ or the desire to share their ethical experience" (Nie 2015: 86), the collective experience that engendered specific value systems and finally a particular historical context. As Nie insists, "ethical literary criticism does not simply evaluate a given literary work as good or bad on the basis of today's moral principles. Instead, it emphasizes 'historicism' that is the examination of the ethical values in a given work with reference to a particular historical context or a period of time in which the text under discussion is written" (Nie 2015: 84).

This perception of the tripartite context facilitating literary practice corresponds with the view of a number of black American womanist theoreticians and writers who refer to a specific black American ethical experience that gave rise to black womanist literary expressiveness. First and foremost, following such major $20^{\text {th }}$ century political and cultural movements as the Civil Rights Movement and the Black Aesthetics Movement, within which many black women felt silenced by both dominant black male leadership along with the two mainstream white feminist waves that served primarily the interests of white middle-class women, a circle of black women felt they needed to convey their own particular perspective of black American experience that to a significant measure was ethical in nature. Furthermore, several other black women writers engaged in reconstructing the history and ethical dimension of collective black American experience. Katie Geneva Cannon succinctly notes, “The Black woman's literary tradition is a source in the study of ethics relative to the Black community" (Cannon 1988: 77). Black American womanist literary practice, therefore, emerged from black women's resistance to historically conditioned marginalization within political and cultural movements and from a need to produce literature that would be a vehicle expressive of unorthodox value system that oppression and marginalization generated. 


\section{The Conceptual Map of Ethical Literary Criticism and Womanist Literature}

Certain themes that black American womanist literary theorists concentrate upon can be approached by means of concepts proposed by Nie Zhenzhao. As before mentioned, Katie Geneva Cannon alludes to the ethical dimension of womanist literary representations of the black community when she writes of it as an assembly that has developed particular values advocating black people's liberation "from the often deadly grasp of parochial stereotypes" (Cannon 2003: 62). With regard to stereotypical images of black men, bell hooks writes, "Read any article or book on black masculinity and it will convey the message that black men are violent. The authors may or may not agree that black male violence is justified, or a response to being victimized by racism but they do agree that black men as a group are out of control, wild, uncivilized, naturalborn predators" (Hooks 2004: 47), and with regard to black women, Angela Davis notes, "Though Black women enjoyed few of the dubious benefits of the ideology of womanhood, it is sometimes assumed that the typical female slave was a house servant - either a cook, maid, or mammy for the children in the "big house." [...] - stereotypes which presume to capture the essence of the Black woman's role during slavery. (Davis 1983: 8).

By and large, the conceptual map systematized by Nie Zhenzhao offers an instrumental tool in ascertaining the ethical dimension of such negative stereotypes and of the salvific means whereby the black community challenges them, the process that is reconstructed in literature by some black American women writers. Nie's concepts of natural selection, ethical selection, and ethical consciousness render the exploration of the literary depictions of the ethically complex stereotypes of black people quite intriguing.

In their peculiar experience of oppression in America, black people have been forced to face the Sphinx factor that Nie Zhenzhao explains as follows,

There are two factors about Sphinx: animal factor and human factor. The animal factor is animal remains coming from ape or animal, but human factor is the new gain from ethical selection. It is animal factor and human factor that determine man to be animal man or ethical man. As the human factor of Sphinx is the major one, the ethical man is more human being than animal man”. (Ross 2015: 12) 
ŁOBODZIEC

Generally, as Nie Zhenzhao contends,

The nature of ethical selection lies in man's decision to be a human or an animal, and the precondition of this decision is the knowledge about man's self or about what distinguishes human beings from animal. [...] When human beings acquired their figures through natural selection, they also found that they still retained many animal features, such as the instinct to survive and to reproduce. (Nie 2015: 96)

In America, black people experienced the effects of natural selection vis-à-vis ethical selection in that they were subjected to dehumanizing categorization that they later challenged and transcended by affirming their humanity. As far as literary representations are concerned, black American experience portrayed by many black American women writers involves black people's struggle against the dehumanizing effects of natural selection towards self-affirmation by way of voluntary ethical selection. This struggle adds a broader context to Nie Zhenzhao's conceptualizations, particularly the natural selection, for he maintains, "natural selection undergoes by way of evolution while ethical selection undergoes by way of teaching and learning" (Ross 2015: 14). The natural selection that black people underwent in America was far more conscious than evolutionary.

Referring back to stereotypes, some black American women writers allude in their narratives to western essentialist racial conceptualizations that engendered a perverse value system. At a certain juncture of societal development, these conceptualizations imaged black people as ontologically inferior, therefore naturally less human. Toni Morrison notes, "For three hundred years black Americans insisted that 'race' was no usefully distinguishing factor in human relationships. During those same three centuries every academic discipline, including theology, history, and natural science, insisted 'race' was the determining factor in human development" (Morrison 1988: 126). The human development that Morrison refers to may be deemed analogous to ethical selection, a process that subjugated African Americans sought to establish to counteract white supremacist natural selection that attempted to preclude black human development. The myriad black responses to natural selection are leitmotifs in many literary works of black American women writers.

As far as the genesis of the ethical humiliation of black people is concerned, Toni Morrison in her novel A Mercy portrays a black woman's first encounter with white supremacist fantasy of the demonic nature of blackness. A black woman named Florens enters by happenstance the house of a white woman called Widow Ealing, wherein a gathering of a white religious assembly is 
taking place. One woman claims that Florens' blackness is a sign of "The Black Man. [...] his minion" (Morrison 2008: 131). The Christian women proceed to examine the black woman's body, searching for demonic stigmata. Florens is disoriented and ashamed as they gaze upon her and narrates her experience as follows,

Eyes that do not recognize me, eyes that examine me for a tail, an extra teat, a man's whip between my legs. Wondering eyes that stare and decide if my navel is in the right place if my knees bend backward like the forelegs of a dog. They want to see if my tongue is split like a snake's or if my teeth are filing to points to chew them up. To know if I can spring out of the darkness and bite. Inside I am shrinking. (Morrison 2008: 135)

This passage depicts outrageous dehumanization by associating her physiognomy with bestial and demonic features. The white women approach her as if she were a primal evolutionary specimen, stemming from the natural selection stage of human development. Florens perceives that their gaze does not acknowledge her humanity but dismisses her personal, human emotions when they examine her body. Their observations also have interesting ethical connotations. The association of the black woman's body with the Black Man is reflective of the "common euphemism for the Christian devil, whom the Puritans associated with the forested wilderness that surrounded their settlements and with the Native Americans who dwelled within it" (Hawthorne 2000: 250). The search for a snake-like split tongue in Florens' mouth evidences suspicion of being confronted by a bestial demon. Therefore, from their warped white supremacist standpoint, Florens is the embodiment of ontological and axiological inferiority. This dehumanizing encounter has a permanent disorienting effect on Florens, who, till the very end of her narrative seems to be in a quandary regarding her self-integrity, individual freedom, and social status. At times she affirms the beauty of her own body and that of her lover, the blacksmith, longing for an independent family that she could have possibly established with him. Her overall experience as an enslaved and dehumanized woman induces the slave syndrome, manifesting itself in an inferiority complex.

Morrison portrays the white Christian sect's creed as being based upon religiously determined racial misconceptions, as does Henry Louis Gates, who views racial conceptualizations as misnomers and metaphors, "arbitrary constructs, not reports of reality. [...] These usages develop simultaneously with the shaping of an economic order in which the cultures of color have been dominated in several important senses by Western Judeo-Christian, GrecoRoman cultures and their traditions" (Gates 1985: 6). Gates' statement alludes to 
biblical associations of blackness with evil and moral depravation and whiteness with good and purity that were employed to impose black ontological and moral inferiority rationalizing relegation of African Americans to the lowest ranks of the American social ladder.

Some white American Christians even engaged biblical hermeneutics to propagate black enslavement. In Morrison's A Mercy, Rebekka Vaark, an English woman who was sold by her parents to a Dutchman called Jacob Vaark, developed her Anglo-American identity as a plantation mistress, began to associate herself with Baptist fundamentalists who regarded themselves as God's anointed people as opposed to the "children of Ham" (Morrison 2008: 108), i.e black people. Morrison here makes a reference to the Hamitic Myth. The African American Biblicist Cain Hope Felder notes that Europeans incorporated the Hamitic Myth "as a justification for slavery and stereotypical aspersions about Blacks" (Felder 1990: 38). Black Theologian James H. Cone cites white Christian catechisms that were composed to create a peculiar ethical order,

producing mental servitude among blacks. [...] Slave catechisms were written to insure that the message of black inferiority and divinely ordained white domination would be instilled in the slaves. Q. What did God make you for? / A. To make a crop. / QWhat is the meaning of "Thou shall not commit adultery?” / A: To serve our heavenly Father, and our earthly master, obey our overseer, and not steal anything. (Cone 1998: 22-23)

To sum up, in Morrison's A Mercy, many statements made by white Christian characters reveal the white supremacist religious mindset foundational to the resulting ethical order that later effectuated a racialist social order. In general, in terms of ethical literary criticism, the novel "refers to the ethical relationship or ethical order between man and man, man and society, [and] to the moral conceptions based upon ethical order, or the relevant norms used to maintain the ethical order" (Nie 2015: 88-89). Morrison here notes the religious indoctrination that rationalized the ontological, therefore, ethical, inferiority of blacks and sanctioned racial slavery as an evangelizing institution by which white Christians morally instructed heathen and unethical enslaved blacks. In practice, the putative ethical order abetted the formation of a white supremacist power structure.

In Morrison's most acclaimed novel, Beloved, the author adverts to the pseudo-scientific dehumanization of enslaved blacks, a form of imposed natural selection that impended black people's volitional ethical selection. Morrison portrays a fictional plantation named Sweet Home, whereupon the schoolteacher utilizes pseudo-scientific means to gauge the subordination of the enslaved black 
woman called Sethe. Adhering to phrenology, he measures her face with a string, and posing as a natural historian, he instructs his students to "put her human characteristics on the left; her animal ones on the right" (Morrison 1987: 193) in describing her. Schoolteacher's practice reflects a misapplication of natural history that seeks "to observe, compare, measure, and order animals and human bodies (or classes of animals and human bodies) based on visible, especially physical, characteristics. These characteristics permit one to discern identity and difference, equality and inequality, beauty and ugliness among animals and human bodies" (West 1982: 55, italics in the original). This solely physicaloriented approach to humanity dismisses ethical identity. The schoolteacher, therefore, is emblematic of western pseudo-scientists, who attempted to validate black inferiority to support American socio-economic order where whites were represented as enlightened human beings, and blacks were relegated to quasihumans.

Sethe is absolutely astounded by the schoolteacher's remarks,

I was about to turn around and keep on my way to where the muslin was, when I heard him say, "No, no. That's not the way. I told you to put her human characteristics on the left; her animal ones on the right. And don't forget to line them up." I commenced to walk backward, didn't even look behind me to find out where I was headed. I just kept lifting my feet and pushing back. When I bumped up against a tree my scalp was prickly. One of the dogs was licking out a pan in the yard. I got to the grape arbor fast enough, but I didn't have the muslin. Flies settled all over your face, rubbing their hands. My head itched like the devil. Like somebody was sticking fine needles in my scalp. I never told Halle or nobody. (Morrison 1987: 193)

Images of a dog, flies, and the devil the incident conjures up underscore the intensity of her internal human crisis evoked by the schoolteacher's outrageous references to her supposedly animalistic characteristics. Her strong emotional reactions are defensive measures against dehumanization.

Later on in the novel, Morrison reconstructs even more intricately Sethe's struggle to hold on to her ethical, human self. Sethe runs away from the Kentucky plantation to join her manumitted mother-in-law, Baby Suggs, in Ohio. Unfortunately, the schoolteacher and other slave catchers find her. When Sethe sees them approaching her abode 124, she gathers her four children, locks herself up with them in a barn, and attempts to kill her children to avoid the inhumanity of enslavement. She succeeds in killing only her infant, Beloved, before the white men intervene. This unsettling portrayal is a literary reconstruction of an actual incident involving Margaret Garner, a black woman who chose infanticide to 
free her children from the threat of lifelong enslavement. Morrison demonstrates that slavery's extremity engendered within Sethe an unorthodox value system, wherein "the mercy killing" of a child by its mother was deemed more moral than allowing the child to suffer human debasement. In the narrative, Sethe's daughter, Denver, conveys a telling explanation of Sethe's decision to commit infanticide:

what it meant - what it took to drag the teeth of that saw under the little chin; to feel the baby blood pump like oil in her hands; ... Sethe could make her realize that worse than that - far worse - was .... That anybody white could take your whole self for anything that came to mind ... Dirty you so bad you couldn't like yourself anymore ... she could never let it happen to her own. The best thing she was, was her children. Whites might dirty her all right, but not her best thing, her beautiful, magical best thing - the part of her that was clean. (Morrison 1987: 251)

To a former enslaved and dehumanized mother, the decision to take the lives of her children was an ultimate act of individual human freedom, a step forward towards ethical selection, whereby she consciously adhered to her own thoughts and emotions in seeking to assert and protect her own and her children's human dignity.

Alice Walker, another black American writer, illustrates in her novel Now Is the Time to Open Your Heart the western pseudo-scientific relegation of a black woman to subhuman status, according to perverse ideations of normality and abnormality. In Walker's novel, a middle aged black woman called Kate Talkingtree sets off on a spiritual journey, during which she joins other troubled people of different races and nationalities, who engage in purifying rituals, sharing of life stories, and conversing about contemporary matters. During one particular gathering, Kate learns of an African woman called Saaritjie Bartmann in an article published in Jet, a black American periodical. This is a reference to the tragic story of Sara "Saartjie" Baartman, an African woman born around 1789, who was deceived and coerced by European colonizers into 'signing' a contract, and was trafficked to London, "where she was displayed in a building in Piccadilly, a street that was full of various oddities like 'the ne plus ultra of hideousness' and 'the greatest deformity in the world.' Englishmen and women paid to see Sara's half naked body displayed in a cage that was about a metre and half high. She became an attraction for people from various parts of Europe" (South African History Online 2013). Caged like an animal in a zoo, she was subjected to abject dehumanization. Paradoxically, she was marketed as the "Hottentot Venus," a composite name of her own people, the Khoi, and the 
Roman love goddess. Several characters in Now Is the Time to Open Your Heart challenge Sara's degradation by imagining her as an embodiment of authentic love. During the women's spiritual journeys, Sara begins to appear in their dreams. One character dreams of her as a "mother looking at her child. Not just her child, but her favorite, best, child. And then, she raised the jar level with her heart [...] and it disappeared into her heart" (Walker 2004: 115), while another character dreams of Saartje wearing bright colored clothing, holding a glass jar, and having on her face the expression of "pure love" (Walker 2004: 115). The women discover that her seeming spiritual presence has a consoling effect on them. They begin to perceive her as a caring ancestor and transcend her misfortune by revering her. As Kate relates in the novel, "We began to pray to Her. To Saartjie who, through Jet magazine, had come to us. We designated her a saint" (Walker 2004: 117). Though explicitly surreal, Alice Walker's literary incorporation of Saarjie Bartmann history in her fictional narrative may be interpreted as a call to look back and acknowledge Bartmann's humanity and moral identity, and render her as a personification of ultimate love. One character recounts that in her dream Saartjie was wearing a cape made of thorns and that she does not "mind the connection with Jesus" (Walker 2004: 117), a statement that places consideration of Bartmann's dehumanization in an ethical context.

As cited earlier, Nie defines intellectual development as another stage in the pursuit of ethical identity by way of ethical selection that proceeds "by way of teaching and learning. We make choices (that is our choice behaviors) throughout our lives but we can't make the right choice without teaching and learning" (Ross 2015: 14). Accordingly, the black American woman writer Gloria Naylor in Bailey's Cafe portrays a black man's endeavor to assert ethical identity through intellect over against white racist association of blackness with barbarity. Stanley's father is a financially secure middle class black man, whose success was viewed by the Gatlin brothers, the poor whites, with hostile envy. There is an incident wherein they accost the black man and his son with ethical degradation. When Stanley's father sees him off as he leaves to enter prestigious Stanford University, the Gatlin brothers egregiously assault them. One Gatlin is riled at the immaculate style of dress the black learned men are wearing: "Well, my brothers and me was out there asking ourselves how it is that a low-down, scum-bag, filthy piece of shit like you - ya know, something that looks like it swung from the jungle - how it is that he thinks he can parade all up and down town wearing them clothes?" (Naylor 1992: 179), while two other Gatlins associate them with primates: "My God, look, it ain't got a tail after all” (Naylor 1992: 180), further jibing "I was gonna put me in a collect call to Louie B. Mayer - up in Hollywood. And tell him he could buy a coupla apes real cheap for his new Tarzan movie" (Naylor 1992: 181). Their utterances are 
ŁOBODZIEC

replete with "pseudoscientific or Darwinian language" (Leiter 2010: 42) that relegate black men to "social monstrosity" (Van Evrie qtd. in Leiter 2010: 42) or "an ape" (Carroll qtd. in Leiter 2010: 42). In ethical terms, animal and human factors enter in. While the learned middle class black man projects himself as an ethical human being, the uncouth undereducated white men seek to attribute a bestial nature to him.

Stanley's father comports himself civilly until he has no other choice than to respond violently in self-defense. When the father and son began to resist, the white man ripped "off every stitch of [their] clothing" (Naylor 1992: 180) and flung the two unclothed black men into a storeroom, continuing to offend them and dehumanize them to primate level by kicking "a banana peel under the door" (Naylor 1992: 180-181) of the storeroom. Stanley's father then concluded, "I see they are determined to leave me no choice. Now I'll have to go back out there and speak to them" (Naylor 1992: 183). With the only clothing available in the storeroom, he dressed himself in a performer's attire and hoped to go out and peacefully dialogue with their assailants. With his efforts failed, he grabbed the 'fat' Gatlin "by the collar, [...] slammed his face on the counter and dragged his unconscious body along the whole length of it" (Naylor 1992: 184), then he trounced the other brothers, projecting himself as a black man "more intelligent [...] physically fit [...] shrewd and ruthless [...] [and] wealthier” (Naylor 1992: 185) than his antagonists.

The confrontation of the learned black man with the boorish white males manifests an endeavor to assert ethical identity in challenge to white supremacist natural selection. Only when the father's self-defense strategies based on his philosophy of non-violence and civility prove to be of no avail, does he reciprocate. At this point, Stanley's father seems to have temporarily adopted the Darwinian notion of the survival of the fittest in that he asserted dominance, but the fact that he first tried to defuse the situation with peaceable and witty measures evidences a strong ethical identity that his white adversaries sought to denigrate. Later, the father confided to his son what he had sought to teach him: "I wanted their words to be babble, whatever they printed, whatever they sent over the radio. Babble - as you learned your own language, set your own standards, began to identify yourself as a man. [...] Forgive me for pressing you so hard and so quickly to become a man" (Naylor 1992: 182). Unfortunately, his son, Stanley, soon learns that a black man's efforts to assert ethical identity in a white supremacist context is a perennial struggle against politically and culturally imposed white natural selection. 
Intersections of African-American Womanist Literary Approaches

\section{Conclusions}

The analysis of the literature of the contemporary black American women writers carried out in this article evidences a certain convergence of ethical literary criticism paradigms and womanist literary approaches at various junctures. Nie Zhenzhao posits, "The overarching aim of ethical literary criticism is to uncover ethical factors that bring literature into existence and the ethical elements that affect characters and events in literary works" (Nie 2015: 10). Correspondingly, black American womanists assert that the particular ethics that black women developed under oppression is the foundation of their literary practice, whereby they communicate the origins of a specific value system that emerged within the black community, corresponding with again ethical literary criticism's call for a historical approach to literary representations of ethical orders. The value system that black experience in America fostered, starting from slavery to racial segregation and then post-Jim-Crow racial discrimination, encompassed and encompasses depravation of individual freedom. Katie Geneva Cannon discusses the ethical dimension of this dilemma in the following way,

Dominant ethics $[\ldots]$ assumes that a moral agent is to a considerable degree free and self-directing. Each person possesses self-determining power. For instance, one is free to choose whether or not she/he wants to suffer and make sacrifices as a principle of action or as a voluntary vocational pledge of crossbearing. In dominant ethics a person is free to make suffering a desirable moral norm. This is not so for Blacks. For the masses of Black people, suffering is the normal state of affairs. Mental anguish, physical abuse and emotional agony are all part of the lived truth of Black people's straitened circumstances. (Cannon 1988: 2-3)

The key element in Cannon's observation is individual choice. Correspondingly, Nie Zhenzhao maintains that the choices individuals make "determine our ethical identity" (Ross 2015: 13), and that to be able to make the right choices people need proper intellectual development, "teaching and learning" (Ross 2015: 14), experiencing ethical selection as opposed to evolutionary natural selection. In the context of American oppression, the whites devised systems that sought to deprive black people of developing ethical identity. In order to maintain the white supremacy, malicious stereotypes that imaged black men and women as ethically inferior human beings or bestial in nature were propagated. As the above novels instruct, biblical hermeneutics was utilized to demonize black people along with pseudo-scientific, Darwinian misinterpretation. The employment of pseudo-scientific theories yielded a specific character exposed 
ŁOBODZIEC

to natural selection in which black people in America were positioned to experience natural selection not as an evolutionary process, but as the outcome of an imposed ethical order. The power structure sought to inculcate in black people the belief in their supposedly natural inherited ethical inferiority and intellectual underdevelopment, as if they had stagnated at an evolutionary stage much earlier than alleged Caucasian representatives of the master race.

In addition to referencing and specifying the origins and utilization of dehumanizing stereotypes, black American women writers also put forward various ways black people have responded to such stereotyping, such as the disoriented Florens in A Mercy, the infanticide in Beloved, the recognition of black woman's loving kindness in Now Is the Time to Open Your Heart as well as the emphasis on intellectual development and non-violence of Stanley's father in Bailey's Cafe. The first two novels depict the ethical inner dilemma of a victimized black woman, and the other two illustrate postures that challenge oppressive ethical orders. Since individual choice, or the lack thereof, is a sort of leitmotif in representing character experiences, the literary depictions have ethical dimensions, by which the novels intersect with the functionality of literature that ethical literary criticism proposes in that they portray "moral rules at play in a given set of circumstances" (Nie in Ross 2015: 14) and offer "enlightenment, education, instruction, and guidance" (Nie in Ross 2015: 14).

\author{
Agnieszka Lobodziec \\ agnieszka.lobodziec@protonmail.com \\ Institute of Modern Languages Studies \\ Uniwersytet Zielonogórski \\ al. Wojska Polskiego 71a \\ 65-762 Zielona Góra \\ POLSKA / POLAND
}

\title{
References
}

Baker, W., Shang Biwu. 2015. Fruitful collaborations: Ethical Literary Criticism in Chinese Academe. - TLS, 31.07, 14-15.

Cannon, K. G. 1988. Black Womanist Ethics. Atlanta: Scholars Press.

Cannon, K. G. 2003. Katie's Canon: Womanism and the Soul of the Black Community. New York: Continuum.

Christian, B. 1988. The Race for Theory. - Feminist Studies, 14.1, 67-79.

Cone, J. H. 1998. The Spirituals and The Blues. New York: Orbis Books.

Davis, A. Y. 1983. Women, Race, and Class. New York: Vintage.

Felder, C. H. 1990. Troubling Biblical Waters: Race, Class, and Family. Maryknoll: Orbis Books. 
Intersections of African-American Womanist Literary Approaches

Gates, H. L. Jr. 1985. Editor's Introduction: Writing 'Race' and the Difference It Makes. - Critical Inquiry, 12. 1, 1-20.

Hall, D. E. 2001. Literary and Cultural Theory: From Basic Principles to Advanced Application. Boston: Houghton.

Hawthorne, N. 2000. The Scarlet Letter. New York: The Modern Library.

Hooks, B. 2004. We Real Cool: Black Men and Masculinity. New York and London: Routledge.

Joyce, A. J. 1994. Warriors Conjurers and Priests: Defining African-centered Literary Criticism. Chicago: Third World Press.

Joyce, A. J. 1996. The Black Canon: Reconstructing Black American literary Criticism. - http://xroads.virginia.edu/ drbr/joyce.html (16.11. 2017).

Leiter, A. B. 2010. In the Shadow of the Black Beast: African American Masculinity in the Harlem and Southern Renaissances. Baton Rouge: Louisiana State UP.

Mori, A. 1999. Toni Morrison and Womanist Discourse. New York: Peter Lang Publishing, Inc.

Morrison, T. 1987. Beloved. Berlin: Vintage.

Morrison, T. 1988. Unspeakable Things Unspoken: The Afro-American Presence in American Literature. - The Tanner Lectures on Human Values. The University of Michigan. 7 Oct. 1988. http://tannerlectures.utah.edu/_documents/a-to-z/m/ morrison90.pdf (16.01.2016).

Morrison, T. 2008. A Mercy. New York: Vintage Books.

Naylor, G. 1992. Bailey's Cafe. New York: Vintage.

Nie, Z. 2015. Towards an Ethical Literary Criticism. - Arcadia, 50.1, 83-101.

Ross, C. 2015. A Conceptual Map of Ethical Literary Criticism: An Interview with Nie Zhenzhao. - Forum for World Literature Studies, 7.1, 7-14.

Shang Biwu. 2014. The Rise of a Critical Theory: Reading Introduction to Ethical Literary Criticism. - 外国文学研究, 年第5 期, 26-36.

South African History Online. http://www.sahistory.org.za/people/sara-saartjiebaartman (08. 08. 2015).

Walker, A. 2004. Now Is the Time to Open Your Heart. New York: Random House.

West, C. 1982. Prophesy Deliverance: An Afro-American Revolutionary Christianity. Philadelphia: The Westminster Press. 